\section{Meget godt om hjertesykdommer}

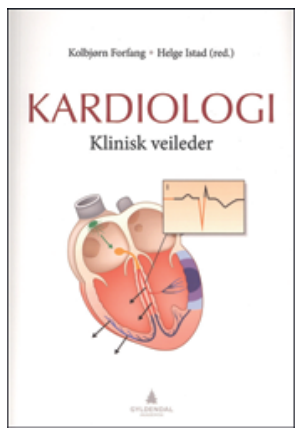

Kolbjørn Forfang, Helge Istad, red. Kardiologi

Klinisk veileder. 344 s, tab, ill. Oslo: Gyldendal Akademisk, 2011. Pris NOK 475

ISBN 978-82-05-41217-0

Bidragsyterne har lagt vekt på å nå et relativt bredt publikum av leger, medisinstudenter og andre fagpersoner med interesse for hjertesykdommer. Ambisjonsnivået er klart preget av den tilsiktede målgruppen ved at boken skal være forståelig, interessant og samtidig gi innblikk i et høyteknologisk og sterkt forskningspreget fagfelt. Resultatet er jevnt over meget godt, til dels glimrende, og uten snev av bunnivå. En mulig interesseskare som ikke er nevnt av forfatterne, er kardiologer innen et nisjefelt som ønsker rask oppdatering innen andre kardiologiske områder.

Læreboken har en tradisjonell inndeling i fagkapitler. De to redaktørene, Forfang med lang erfaring i høyspesialisert kardiologi, og Istad som privatpraktiserende indremedisiner, har tydeligvis utfylt hverandre både $\mathrm{i}$ valg av tema og $\mathrm{i}$ å bestemme vanskelighetsgrad for stoffet som presenteres. Resultatet er en suksessfull symbiose, kjennetegnet ved at det ikke kan erklæres en vinner blant de to $\mathrm{i}$ form av for mye teknikk og høyspesialisert medisin, eller for lite. Samtidig er det vanskelig å påpeke mangler.

Redaktørene har fått med seg et solid panel av erfarne kolleger, og det står mye forskningserfaring bak produktet. Dette er generelt sett kun en styrke, men kan også blende litt slik at kanskje redigeringen og de kritiske spørsmålene kan ha uteblitt noe enkelte steder. Kontraindikasjonene til å utføre arbeidstest i isotopkapitlet kunne vært redigert noe, og forfatterne gjør heller ikke noe forsøk på å diskutere om slike tids- og personalkrevende undersøkelser, med høy grad av ioniserende stråling, bør vektlegges mindre fremover, fordi det foreligger strålefrie alternativer. Indikasjonsangivelse for noen av undersøkelsene i diverse kapitler kan fremstå lite bearbeidet. Alt i alt er dette småting og helt klart gjenstand for faglig diskusjon. Redaktørene påpeker selv at det spesielt er vanskelig å skrive om antitrombotisk behandling fordi fagfeltet beveger seg så raskt. Selv om kapitlet er godt skrevet og helt oppdatert ved utgivelse, kan det være grunn til å diskutere om et eget kapittel for et slikt tema hører mer hjemme i en oversiktsartikkel enn i en lærebok, nettopp på grunn av de stadige oppdateringsbehovene.

Det har vært ambisiøst å sette i gang med dette prosjektet. Hjertesykdom er en viktig folkesykdom i vår tid, noe som medfører at det er mange høyprofilerte kolleger innen hvert enkelt kapittel som omtaler de enkelte kardiologiske fagfeltene. Det er således lett å stille seg lagelig for hogg, og det er mange som både kan og vil mene noe om nivå og form som er valgt. Oppgaven er imidlertid løst «meget godt», noe som både er en beskrivelse og en anerkjennelse. I tillegg kan også oppfattes å henspille på et for redaktørene kjent karaktersystem fra tidligere skoledager.

Mange kan glede seg til å lese denne boken.

\section{Jan Erik Nordrehaug}

Hjerteavdelingen

Haukeland universitetssykehus

\section{Kroppsvask - disiplinering eller fagkunnskap?}

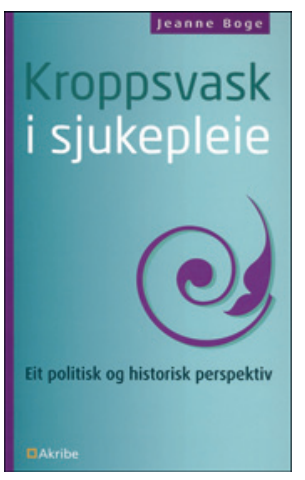

\author{
Jeanne Boge \\ Kroppsvask i sjukepleie
}

Eit politisk og historisk perspektiv. 103 s, tab. Oslo: Akribe, 2011. Pris NOK 198

ISBN 978-82-7950-150-3

Hvordan kan det ha seg at kroppsvask er et politisk interessant anliggende, spør Boge innledningsvis i boken som er basert på hennes ph.d.-avhandling Kroppsvask i sjukepleie (2008).

Med Michel Foucaults argumentasjon for renslighet som et dannelses- og disiplineringsprosjekt i forbindelse med industrialiseringen av vestlige samfunn, analyserer Boge begrunnelsene for kroppsvask i sykepleie. Analysen er basert på studier av norske lærebøker i sykepleie fra 1877-1911, 1967 og 2004, på Eilert Sundts studie Om Renligheds-Stellet i Norge (1869) og på observasjoner og intervju av pleietrengende og pleiere i et norsk sykehjem i 2002 og 2006.

Boge argumenterer for at borgerlige renslighetsnormer har preget sykepleiefaget, selv om legitimeringen av dem har endret seg i pakt med politiske og økonomiske interesser.

Boken er lettlest og gir mange innsikter av betydning for dagens sykepleieutøvelse. Spesielt er siste del et viktig bidrag i debatten om forholdene i dagens sykehjem. Det er videre prisverdig at kroppsvask og renslighet i sykepleie er gjenstand for forskning. I fremveksten av sykepleiefaget er det vel neppe noe tema som har hatt så stor betydning for utviklingen av faget som renslighet og hygiene.

Når det er sagt, er det viktig å påpeke at når Boge hevder at detaljerte vaskeinstruksjoner ble nedfelt i lærebøkene som et resultat av disiplinering og implementering av borgerlige kvinneverdier i sykepleiefaget, underkjenner hun samtidig en vesentlig del av fagets kunnskapsgrunnlag. Fordi sykepleie handler om å ta seg av den syke gjennom et sykdomsforløp, har nødvendigvis forståelsen av sykdommer satt sitt preg på fagtradisjonen. Slik har kampen mot smittsomme sykdommer som sykepleierne tok aktivt del i, lagt et vesentlig grunnlag for smittetiltak og prosedyrer i sykepleie.

For å videreutvikle sykepleiefaget trenger vi studier som løfter frem den konkrete og praktiske sykepleieutøvelsen over tid. Historiske studier av sykepleiepraksis er en vesentlig del av grunnforskningen i sykepleie fordi de bidrar med viktige teoretiske perspektiver og kontekst til empiriske studier av dagens sykepleieutøvelse. Slike studier krever imidlertid metodologiske overveielser som erkjenner at sykepleierne i liten grad har etterlatt seg skriftlige kilder og at lærebøker fra dette tidsrommet ikke nødvendigvis gjenspeiler utøvelsen av faget.

\section{Åshild Fause}

Institutt for helse- og omsorgsfag

Det helsevitenskapelige fakultet

Universitetet i Troms $\emptyset$ 